\title{
The Quality of Democracy In Europe: Its Impact On Economic, Political and Social Performance
}

\author{
Kristobal Miguel Meléndez Aguilar
}

\section{Doi:10.5901/ajis.2015.v4n3s1p103}

\section{Abstract}

The quality of democracy is a new concept that tries to explain the reason why democracies have different levels of performance. In 1959, by calculating average of some variables of welfare, Lipset showed that democracies have a better economic performance than another type of regime. By applying simple linear regressions and instrumental-variables regressions, it was found that the Rule of Law, accountability through voting and accountability through the institutions cause economic and social performance in Europe. Electoral participation and membership do not have a direct effect on the results that government offers, but make these procedural elements more effective. In the same way, more years of democracy do not guarantee a better performance but also have an indirect effect in the Rule of Law, accountability through voting and accountability through the institutions in Europe. Citizens' perceptions about the quality of democracy in Europe vary to a very slow pace unless there is a great change on the procedural elements.

\section{Introduction}

Lipset argued in 1959 that democracy, compared to other types of regime, offers more wealth, industrialization, education and urbanization ${ }^{1}$. This author compared several variables of welfare and found that there is always a better economic performance in democratic countries versus those countries that are not. Lipset only compared the levels of welfare between two types of regime; but he does not carry out a causality analysis to determine if democracy generates or not a better economic performance. These comparative data seem to be an incentive for democratization. However, this process took place several decades later.

Based on the sample of countries of Polity IV from 1989 to 2010, the number of countries with democracy was doubled from $26.99 \%$ to $54.6 \%$. Since the end of the Cold War, a large number of countries chose this type of regime. This situation grew with more strength in Eastern Europe, only from 1990 to 1991 there was a change from 10.71\% to $50 \%$ of the countries of this region. In 2000, in Eastern Europe, the $57.14 \%$ of the countries were democratic; by 2003 , the $75 \%$ of the region had democratized.

The problem lies in that a lot of young people only have lived in democracy and they could support other types of regime because they ignore the risk of that. Then, it is interesting, as a research question, to investigate if democracy have a positive impact on the performance of European countries or not. In order to test the hypothesis of Lipset that democracies have a better performance than those countries that are not democratic

\section{Methodologhy}

There are two ways in which the quality of democracy can be measured $2,3,4,5$ quantitatively and qualitatively. In this research, the quantitative variables are rule of law, accountability through voting, accountability through the institutions, participation, competition, economic freedom, employment, inequality, poverty, human development, public policy

\footnotetext{
1 Seymour Lipset. (1959). "Some Social Requisites of Democracy: Economic Development and Political Legitimacy". In The American Political Science Review. 53. 1. 76.

2 David Altman and Anibal Pérez-Liñán. (2002, Summer). "Assessing the Quality of Democracy: Freedom, Competitiveness and Participation in Eighteen Latin American Countries". In Democratization. 9. 2. 85-100.

${ }_{3}^{3}$ Michael Coppedge. (2004). "Quality of Democracy and Its Measurement". In Guillermo O'Donnell, Jorge Vargas and Osvaldo lazzetta (eds.). The Quality of Democracy: Theory and Applications. Notre Dame. University of Notre Dame Press. $239-248$. ${ }_{4}^{4}$ Larry Diamond and Leonardo Morlino (eds.). (2005). Assessing the Quality of Democracy. Baltimore. Johns Hopkins University Press.

5 Guillermo O'Donnell. (2004). "Human Development, Human Rights, and Democracy". In Guillermo O’Donnell, Jorge Vargas and Osvaldo lazzetta (eds.). The Quality of Democracy:Theory and Applications. Notre Dame. University of Notre Dame Press. 9-92.
} 
performance, political stability and gender equality. The qualitative variables are importance of democracy, democratic quality perception and life satisfaction.

Chart 1. - The impact of the number of years of democracy in the elements of democratic quality in Europe

\begin{tabular}{|l|c|c|c|c|c|}
\hline Dependent r r riables & $\mathbf{n}$ & Coefficient & P> $>\mathbf{t} \mid$ & R-squared & Prob $>\mathbf{F}$ \\
\hline Accountability through voting & 43 & .0929500 & 0.000 & 0.6324 & 0.0000 \\
\hline Accountability through the institutions & 42 & .1223189 & 0.000 & 0.7325 & 0.0000 \\
\hline Human development & 40 & .0515037 & 0.000 & 0.6800 & 0.0000 \\
\hline Public policy perfomance & 43 & .0861892 & 0.000 & 0.6967 & 0.0000 \\
\hline Rule of law & 43 & .0932050 & 0.000 & 0.7337 & 0.0000 \\
\hline Competition & 43 & .0320178 & 0.006 & 0.1712 & 0.0058 \\
\hline Gender equality & 39 & .0340049 & 0.001 & 0.2220 & 0.0015 \\
\hline Political stability & 43 & .0378932 & 0.000 & 0.3091 & 0.0001 \\
\hline Poverty & 33 & .0271764 & 0.012 & 0.1859 & 0.0120 \\
\hline Economic freedom & 42 & .0345588 & 0.000 & 0.4348 & 0.0000 \\
\hline Employment & 43 & .0178710 & 0.013 & 0.1404 & 0.0133 \\
\hline Inequality & 43 & .0220117 & 0.034 & 0.0339 & 0.0339 \\
\hline Participation & 43 & .0600378 & 0.000 & 0.3932 & 0.0000 \\
\hline
\end{tabular}

Independent variable: number of years of democracy.

Source: Compiled by author based on World Bank, Transparency International, IDEA, UN, Heritage, World Economic Forum, UNDP, CIA and Polity IV.

By applying simple linear regressions and instrumental-variables regressions, it is displayed in a more accurate way the impact that democracy has in political, economic and social performance in Europe. Simple linear regressions were chosen in order to make easier the conceptual understanding. Given that the most of independent variables that will be used are indexes, with the disaggregation of those indexes it could be made some multiple linear regressions with similar results. In order to measure the quality of democracy, in a general way, the procedural elements will be considered as independent variables and the economic and social results will be considered as dependent variables. It is included an analysis of coefficients to show the democratic elements that have stronger impact on performance. In order to compare coefficients, most of variables are standardized in a scale from 0 to 10.

Chart 2 - The impact of procedural elements on economic performance in Europe

\begin{tabular}{|l|c|c|c|c|c|}
\hline Dependent variables & $\mathbf{n}$ & Coefficient & P $>|\mathbf{t}|$ & R-squared & Prob $>$ F \\
\hline Employment \\
\hline All European countries & 45 & 1.227310 & 0.000 & 0.9026 & 0.0000 \\
\hline Democratic & 35 & 1.194494 & 0.000 & 0.9441 & 0.0000 \\
\hline Non democratic & 7 & 2.506369 & 0.000 & 0.8932 & 0.0004 \\
\hline Poverty \\
\hline All European countries & 32 & 1.227978 & 0.000 & 0.9188 & 0.0000 \\
\hline Democratic & 25 & 1.171226 & 0.000 & 0.9552 & 0.0000 \\
\hline Non democratic & 7 & 2.084883 & 0.000 & 0.9174 & 0.0002 \\
\hline Economic freedom & 45 & 1.007365 & 0.000 & 0.9461 & 0.0000 \\
\hline All European countries & 45 & 0.985593 & 0.000 & 0.9707 & 0.0000 \\
\hline Democratic & 35 & 1.863312 & 0.000 & 0.9647 & 0.0000 \\
\hline Non democratic & 7 & 1.863 & \\
\hline Inequality & 45 & 1.117731 & 0.000 & 0.9174 & 0.0000 \\
\hline All European countries & 35 & 1.095956 & 0.000 & 0.9422 & 0.0000 \\
\hline Democratic & 35 & 1.840308 & 0.002 & 0.8085 & 0.0024 \\
\hline Non democratic & 7 & 1 &
\end{tabular}

Independent variable: index of procedural elements.

Note: Regression without constant.

Source: Compiled by author based on World Bank, Transparency Intemational, Heritage and CIA. 


\section{Causality Analysis}

As shown in Chart 1, through comparison with political and social performance, the number of years of democracy in Europe has a small coefficient in the variables of economic performance as poverty, economic freedom, inequality and employment. This means that economic results will last at least double the time than political results for being observed by people. In Europe, 37 and 45 years of democracy are required in order that poverty and inequality, respectively, can improve one point in a scale from 1 to 10. In contrast, in Europe, 8 and 11 years of democracy are required in order that accountability through the institutions and accountability through voting, respectively, can improve one point in a scale from 1 to 10.

As shown in Charts 2 and 3 , in Europe, the index of procedural elements has a very good impact on economic and social performance. The effect is higher in employment, poverty, inequality, human development and political stability. However, in all cases, the progress rate is higher in European non democratic countries. This implies that the gap between both types of regime is narrowing.

Chart 3. - The impact of procedural elements on social performance in Europe

\begin{tabular}{|c|c|c|c|c|c|}
\hline Depend ent rariables & $\mathbf{n}$ & Coefficient & $P>|t|$ & R-squared & Prob $>F$ \\
\hline \multicolumn{6}{|l|}{ Political stability } \\
\hline All European countries & 45 & 1.068432 & 0.000 & 0.9470 & 0.0000 \\
\hline Democratic & 35 & 1.044287 & 0.000 & 0.9695 & 0.0000 \\
\hline Non democratic & 7 & 1.751208 & 0.001 & 0.8688 & 0.0007 \\
\hline \multicolumn{6}{|l|}{ Human Development } \\
\hline All European countries & 43 & 1.173998 & 0.000 & 0.9546 & 0.0000 \\
\hline Democratic & 33 & 1.153746 & 0.000 & 0.9765 & 0.0000 \\
\hline Non democratic & 7 & 2.011690 & 0.000 & 0.9347 & 0.0001 \\
\hline \multicolumn{6}{|l|}{ Public policy performance } \\
\hline All European countries & 45 & 0.986026 & 0.000 & 0.9916 & 0.0000 \\
\hline Democratic & 35 & 0.979329 & 0.000 & 0.9966 & 0.0000 \\
\hline Non democratic & 7 & 1.269429 & 0.000 & 0.9616 & 0.0000 \\
\hline \multicolumn{6}{|l|}{ Gender equality } \\
\hline All European countries & 42 & 0.932084 & 0.000 & 0.9366 & 0.0000 \\
\hline Democratic & 33 & 0.917567 & 0.000 & 0.9694 & 0.0000 \\
\hline Non democratic & 6 & 1.795089 & 0.001 & 0.9106 & 0.0008 \\
\hline
\end{tabular}

As shown in Charts 4 and 5, in Europe, electoral participation makes procedural elements more effective. But membership and political action do not make procedural elements more effective in European democratic countries. In European non democratic countries the effect is much greater. In those countries, membership has a greater indirect impact on the economic and social results. In European non democratic countries, participation is an effective tool for reducing poverty and inequality. It is required less than the half of participation in European non democratic countries in order to solve these two problems. Even, participation could have negative effect in European democratic countries. Participation makes procedural elements less effective for improving gender equality and public policy performance. 
Chart 4. - The impact of procedural elements on economic performance in Europe with in strumental variables

\begin{tabular}{|c|c|c|c|c|c|c|}
\hline \multirow[b]{3}{*}{ Depend ent variables } & \multicolumn{6}{|c|}{ Instrumental variables } \\
\hline & \multicolumn{2}{|c|}{ Participation } & \multicolumn{2}{|c|}{ Membership } & \multicolumn{2}{|c|}{ Political action } \\
\hline & $\mathbf{n}$ & Coefficient & $\mathbf{n}$ & Coefficient & $\mathrm{n}$ & Coefficient \\
\hline \multicolumn{7}{|l|}{ Employment } \\
\hline All European countries & 44 & 1.318221 & 16 & 1.246626 & 15 & 1.181107 \\
\hline Democratic & 35 & 1.234279 & 11 & 1.131654 & 11 & 1.124499 \\
\hline Non democratic & 7 & 2.934341 & 5 & 3.379757 & 4 & 2.994397 \\
\hline \multicolumn{7}{|l|}{ Poverty } \\
\hline All European countries & 32 & 1.308408 & 14 & 1.211240 & 13 & 1.141798 \\
\hline Democratic & 25 & 1.199755 & 9 & 1.079496 & 9 & 1.070741 \\
\hline Non democratic & 7 & 2.375201 & 5 & 2.746123 & 4 & 2.530031 \\
\hline \multicolumn{7}{|l|}{ Economic freedom } \\
\hline All European countries & 44 & 1.051200 & 16 & 0.984514 & 15 & 0.956516 \\
\hline Democratic & 35 & 1.003809 & 11 & 0.921011 & 11 & 0.920312 \\
\hline Non democratic & 7 & 2.002190 & 5 & 2.162708 & 4 & 2.116206 \\
\hline \multicolumn{7}{|l|}{ Inequality } \\
\hline All European countries & 44 & 1.198906 & 16 & 1.164773 & 15 & 1.105454 \\
\hline Democratic & 35 & 1.135124 & 11 & 1.074261 & 11 & 1.070577 \\
\hline Non democratic & 7 & 2.330308 & 5 & 2.844092 & 4 & 2.222662 \\
\hline
\end{tabular}

Independent variable: index of proced
Note: Regression without constant.

Source: Compiled by author based on World Bank, Transparency Intemational, Heritage, IDEA,

World Values Survey and CIA

As shown in Chart 6, by electoral participation levels, in Europe, the procedural elements do not have a substantial influence in the importance of democracy, democratic quality perception and life satisfaction. The number of years of democracy has causal relation with the importance of democracy and with the democratic quality perception. However, in Europe, 46 years of democracy are required in order that the importance of democracy can increase one point in a scale from 1 to 10. In this region, 29 years of democracy are required in order that the democratic quality perception can increase one point in a scale from 1 to 10. This number of years is more than the time since the beginning of the third democratization wave in 1989.

Chart 5. - The impact of the procedural elements on social performance in Europe with instrumental variables

\begin{tabular}{|c|c|c|c|c|c|c|}
\hline \multirow{2}{*}{} & \multicolumn{5}{|c|}{ Instrumental variables } \\
\cline { 2 - 8 } & \multicolumn{2}{|c|}{ Participation } & \multicolumn{2}{c|}{ Membership } & \multicolumn{2}{c|}{ Political action } \\
\hline Depend ent variables & $\mathbf{n}$ & Coefficient & $\mathbf{n}$ & Coefficient & $\mathbf{n}$ & Coefficient \\
\hline Political stability & & & & & & \\
\hline All European countries & 44 & 1.113804 & 16 & 1.073138 & 15 & 1.004669 \\
\hline Democratic & 35 & 1.055977 & 11 & 0.993648 & 11 & 0.971706 \\
\hline Non democratic & 7 & 2.096898 & 5 & 2.547953 & 4 & 2.060563 \\
\hline Human Development & & & & & & \\
\hline All European countries & 42 & 1.231096 & 16 & 1.180840 & 15 & 1.149213 \\
\hline Democratic & 33 & 1.176832 & 11 & 1.106522 & 11 & 1.112476 \\
\hline Non democratic & 7 & 2.274896 & 5 & 2.559692 & 4 & 2.325985 \\
\hline Public policy performance & & & & & & \\
\hline All European countries & 44 & 1.002141 & 16 & 0.983889 & 15 & 0.975578 \\
\hline Democratic & 35 & 0.984416 & 11 & 0.959515 & 11 & 0.957421 \\
\hline Non democratic & 7 & 1.362513 & 5 & 1.436113 & 4 & 1.557181 \\
\hline Gender equality & & & & & & \\
\hline All European countries & 41 & 0.978240 & 16 & 0.956949 & 15 & 0.931187 \\
\hline Democratic & 33 & 0.922057 & 11 & 0.885737 & 11 & 0.898494 \\
\hline Non democratic & 6 & 2.029301 & 5 & 2.278174 & 4 & 1.978435 \\
\hline Independent variable: index of procedural elements. & & & & \\
\hline
\end{tabular}

Independent vaniable: index of proced
Note: Regression without constant.

Source: Compiled by author based on World Bank, Transparency International, WorldE conomic F orum Source: Compiled by author based on
IDEA, World Values Survey and UNDP.

Although the gap between both types of regime is narrowing in Europe, as shown in Chart 6, if procedural elements or electoral participation levels increase, citizens of European non democratic countries prefer democracy or perhaps they are thinking that they are living in a democracy although they do not. 


\section{Conclusions}

Lipset showed that, in all cases, democracies had a better performance than those countries that decided not to be democratic. On a deeper analysis, it was found that European non democratic countries are growing at a greater rate $(3 \%)$ than those European countries that are democratic (0.9\%). This implies that the gap between both types of regime is decreasing over time.

By applying simple linear regressions and instrumental-variables regressions, and analyzing the coefficients of standardized variables, it was found that procedural elements of a democracy produce a better economic and social performance in Europe. It would seem logical that the number of years of democracy and the different types of participation should have a great impact on economic and social performance in Europe. However, by applying instrumental-variables regressions, it was found that such effect exists in an indirect way with electoral participation and membership. Citizens' perceptions about the quality of democracy vary to a very slow pace unless there is a great change on the procedural elements. Therefore, the quality of democracy is important for a better political, economic and social performance in Europe.

\section{References}

Altman, David and Aníbal Pérez-Liñán. (2002, Summer). "Assessing the Quality of Democracy: Freedom, Competitiveness and Participation in Eighteen Latin American Countries". In Democratizat ion. 9. 2. 85-100.

CIA World Factbook. (Of, 1 September 2015, https://www.cia.gov/library/publications/the-world-factbook).

Coppedge, Michael. (2004). "Quality of Democracy and Its Measurement". In Guillermo O'Donnell, Jorge Vargas and Osvaldo lazzetta (eds.). The Quality of Democracy: Theory and Applications. Notre Dame. University of Notre Dame Press. 239-248.

Diamond, Larry and Leonardo Morlino (eds.). (2005). Assessing the Quality of Democracy. Baltimore. Johns Hopkins University Press.

Global Gender Gap Report. (2009). World Economic Forum. (Of, 1 September 2015, http://www.amichediabcd.org/The\%20Global\%20 Gender\%20Gap\%20report2009.pdf).

Heritage. (2009). Ranking the countries. (Of, 1 September 2015, http://www.heritage.org/index/ranking).

Institute for Democracy and Electoral Assistance (IDEA). Voter Turnout. (Of, 1 September 2015, http://www.idea.int/vt).

Lipset, Seymour. (1959). "Some Social Requisites of Democracy: Economic Development and Political Legitimacy". In The American Political Science Review. 53. 1. 69-105.

O'Donnell, Guillermo. (2004). "Human Development, Human Rights, and Democracy". In Guillermo O'Donnell, Jorge Vargas and Osvaldo lazzetta (eds.). The Quality of Democracy:Theory and Applications. Notre Dame. University of Notre Dame Press. 9-92.

Polity IV Project. Individual Country Regime Trends, 1946-2013. (Of, 1 September 2015, http://www.systemicpeace.org/polity/ polity4. htm).

Transparency International. (Of, 1 September 2015, http://www.transparency.org/).

United Nations Development Programme (UNDP). (2009). Human Development Index. (Of, 1 September 2015, http://hdr.undp.org/en/ statistics/).

United Nations. UNSD Stadistical Databases. (Of, 1 September 2015, http://unstats.un.org/unsd/databases.htm).

World Bank. World Development Indicators. (Of, 1 September 2015, http://data.worldbank.org/products/wdi).

World Bank. (2009). Worldwide Governance Indicators. (Of, 1 September 2015, http://info. worldbank.org/governance/wgi/index.asp).

World Values Survey: The World's Most Comprehensive Investigation of Political and Sociocultural Change. (Of, 1 September 2015, http://www.worldvaluessurvey.org). 